\title{
Learning Strategies and English Language Teaching
}

\author{
Ali Akbar Khansir \\ Bushehr University of Medical Sciences, Bushehr, Iran \\ Fatemeh Ghani Dehkordi \\ Bushehr University of Medical Sciences, Bushehr, Iran \\ Mostafa Mirzaei \\ Bushehr University of Medical Sciences, Bushehr, Iran
}

\begin{abstract}
Learning strategy has been an important topic of English language among teachers, researchers and syllabus designers in the history of English language teaching. Learning strategy and English language occupy the central role in teaching and learning in EFL setting. This paper discusses learning strategies and English language teaching in English foreign language in Iran. The aim of this research paper was to report the results of learning strategies of a group of twenty Iranian students of English, doing their post-graduation. The subjects for this research paper were Persian -speaking students doing M.A. course in Persian Gulf University, Bushehr. In this research paper, two sets of questionnaires were conducted. The first set was a background questionnaire consisted of subjects, gender, age and language attitude etc. The other test was the original test of willing (1994) survey included learning strategies questionnaire. This test consisted of twenty nine -items. Results of the analysis of this paper revealed that leaning strategies is an important criterion in getting the English knowledge of EFL students in their class.
\end{abstract}

Index Terms - learning strategies, English language, EFL learners, teaching strategies, English foreign and second language

\section{INTRODUCTION}

The theory of learning strategy has had an enormous effect on empirical studies in language teaching in general and English in particular in the last decades. Today, it has also been used as a methodological tool to teach English in EFL class. Knowledge of the learning strategy as one of the important topics of English language teaching is one thing. Developing competence of this knowledge in English teachers and students is another. A question arises why learning strategy is important in language teaching. Our main point in this paper is that learning strategy gives English teachers and students the tools they need to develop the knowledge of English language in classrooms and is thus an essential part of English language teaching. There is no doubt that learning strategy can successfully handle a number of English problems and it proposes learning strategies in teaching English for teachers. Indeed, we can say that the main aim of learning strategy is to provide English teachers and students with what they need to reach their purpose so that they can progress in the four skills (speaking, listening, reading and writing) in English.

In order to understand and apply English foreign or second language teaching methods, approaches and techniques in ELT class, we need to understand learning strategies. It has been one of the most important phenomena in the history of English language teaching. No doubt learning strategies has influenced on English language teaching in EFL class. The aim of the English language researches based on learning strategy is to develop the knowledge of both teacher and learner in English language in EFL and ESL classes. In the history of English language, we have been witness to discussion of empirical researches based on learning strategy theory in the works of the great researchers in English in recent years such as Reid (1987); O Malley and Chamot (1990); Oxford and Anderson (1995); Cohen (1998); Anderson (2005); and Wong and Nunan (2011). By developing learning English, there is a growing demand for various researches in learning strategies in English.

Learning strategy have attempted to help teachers and students reduce the problems for teaching and learning English as foreign or second language out of English-speaking countries. It can, in fact, be argued that learning strategy is necessary for progress in English foreign language and the researches support the view that the use of the learning strategy is essential in EFL classroom.

In this part, we try to give an introduction about strategy and then, learning strategy will be discussed in the next paragraphs. The first question that a researcher of learning strategy faces with it is that what is strategy? The word of strategy was derived from the ancient Greek term "strategia" that its meaning is art of war (Oxford, 1990). He gave more information about the word of strategy and argued that it involves the optimal management of troops, ships, or aircraft in a planned campaign. Matthews (2011) said that strategy refers to informally in various contexts of a broad 
way of achieving an end. To use an interrogative as request (can you help me?) or might thus be said to be one strategy for influencing the actions of an addressee, or one strategy for politeness; a model of language processing will adopt a strategy for e.g. parsing; and so on. Birjandi and Mosallanejad (2010) argued that strategy is used for specific methods of approaching a problem or task, modes of operation for achieving a particular end, and planned designs for controlling and manipulating certain information.

The following are one research hypothesis and one research question formulated to verify the role of learning strategies in English language involved in this study:

Are there differences in learning strategies to get the English knowledge of EFL students in their class?

There is a significant difference in learning strategies to get the English knowledge of EFL students in their class.

\section{LITERATURE REVIEW}

In the history of English language teaching and learning, many great researchers have worked on learning strategies for increasing knowledge of teachers and learners of English language over the world. One of the language researches has been done by Wong and Nunan in 2011. They investigated on the differences among learning strategies, learning style and patterns of language use by more effective and less effective learners of English as a foreign language. The outcome of this study indicated that English foreign language students have been under the effect of attitudes toward language and learning. The foreign language learners who were more effective seem to be able to develop active learning strategies for themselves. However, the students were agreeing to learn and enjoy English based on selected strategy. Mandasari and Oktaviani (2018) investigated learning strategies in English in versitas Teknokrat Indonesia. They selected students of engineering and management in this university. The result of their work showed that the management and engineering students used a platform of learning strategies. The learners who were selected in this study showed that they had the same strategy in learning English in classroom. Souriyavongsa et al (2013) examined English speaking skill of a group of undergraduate students at the National University of Laos (NUOL). Outcome of this research work indicated that English speaking skill was the most important English skills among the learners who needed to improve in their undergraduate program. This study showed that the learners used frequency English learning strategies in learning English. The researchers of this study said that it is necessary for all administrators, syllabus designers and English teachers should consider all parts of the learners' needs and their learning strategies in the deeper ways in order to correspond to the society and learners' requirements.

\section{IMPORTANT OF THE STUDY OF LEARNING STRATEGIES}

To a research worker interested in the study of learning strategies in English language is thing of very important, because the learning strategies are aspects of language learning in general and English language in particular. In addition to what has been suggested by linguists, is that learning strategies provide important information regarding language learning when learners use them to learn a language. First of all, we consider learning and then define learning strategies as our main issue of this study, learning is called as gaining knowledge, acquiring skills or getting insights, Birjandi et al (2006) argued that Behaviorists define learning as a relatively permanent change in behavior which happens through regular practice. What is interesting for us is that learning is conscious and teachable in learning language and thus artificial material is necessary for learning a language. In other words, learning factors such as motivational and attitudinal factors are necessary for learning language. In learning language, the role of teacher and pupils with material are necessary as the leaning triangle. Khansir (2014) mentioned that the special role of a teacher in learning language as one of angle of the educational triangle is very vital. Teacher uses learning strategies to teach students in the classroom.

Considering the learning strategies in learning language in general and English in particular has been suggested by many great scholars and authors in the history of English language teaching. Nunan (2001, p. 55) mentioned that learning strategies are" the mental and communicative processes that learners deploy to learn a second language". In addition to what has been mentioned by Birjandi et al (2006), regarding to learning strategies is that they are defined as behaviors and thoughts that a learner employs during learning. Leaver et al (2005) defined learning strategies as the term applied to the various behaviors or techniques we use to learn. Some are consciously employed, and others are automatic. Ellis is another research scholar regarding learning strategies said that they are the special techniques or approaches those pupils employ to learn a second or foreign language (2003). Viewing learning strategies from the point of Scarcella and Oxford ( 1992) is that they can be used as specific actions, steps, techniques or even behaviors are used by students to enhance their learning in giving oneself encouragement to tackle a difficult language task or seeking out conversation partners. Johnson and Johnson (1999) defined learning strategies as techniques for organizing samples and remembering of the second language are used by second language students. Naiman et al (1978) defined learning strategies as a good way for language learner to study language. Therefore, it is a known fact that learning strategies are used as one of the main factors in developing English in English foreign language classrooms.

\section{Methodology}


This study followed a scientific method based on a learning strategy method in English language teaching in EFL setting. It is clear that we can reach our aim only through a scientific method in research work. Ravindra Sastry (1984, p. 43) argued that "scientific method is a branch of study which is concerned with observed facts systematically classified, and which includes trustworthy methods for discovery of truths". In this study, we use questionnaire method. Questionnaire method is the one in which data are collected by making use of a questionnaire. In this study, the two kinds of questionnaires were prepared and administered for the present research work, namely a learning strategies questionnaire, adapted from the original willing (1994) survey and another questionnaire of this paper is a background questionnaire. On this basis the first test included a twenty nine -item questionnaire and the second types of this paper test consisted of participant's information such as age, gender and language attitude etc.

\section{B. Participants}

Twenty students were studying in English language at Persian Gulf University in Bushehr city, Iran has been selected as subjects for this research. The subjects selected speak Persian language as their mother tongue. English as foreign language has been used by the subjects in EFL class. In other words, Khansir and Gholami Dashti (2014) added that English as foreign language has been used as a subject from middle (Guidance) school. Khansir (2020) supported this claim and said that English is used as a foreign language in Iran and English is taught in schools, often widely, but it does not play an essential role in national or social life. The fact that the vast majority of English syllabuses in school, university situations in Iran are paid attention to teaching English through grammar rules .20 post-graduation students included of 9 female and 11 male were selected for this research.

Sex and Frequency of Subjects are presented in the following table:

TABLE (1)

SEX AND FREQUENCY OF LANGUAGE LEARNERS

\begin{tabular}{|c|c|c|}
\hline Sex & Frequency & Percent \\
\hline Female & 9 & 45.0 \\
\hline Male & 11 & 55.0 \\
\hline Total & 20 & 100.0 \\
\hline
\end{tabular}

The age and percentage of Persian Gulf University post-graduate students are given below. The Iranian learners were in the age range of 24 to 30 . However, the age and percentage of the students are mentioned in the following table:

TABLE (2)

AGE AND FREQUENCY OF THE IRANIAN STUDENTS

\begin{tabular}{|c|c|c|}
\hline Age & Frequency & Percent \\
\hline 24 & 7 & 35.0 \\
\hline 25 & 1 & 5.0 \\
\hline 26 & 1 & 5.0 \\
\hline 27 & 2 & 10.0 \\
\hline 28 & 2 & 10.0 \\
\hline 29 & 4 & 20.0 \\
\hline 30 & 3 & 15.0 \\
\hline Total & 20 & 100. \\
\hline
\end{tabular}

In terms of analyses of enjoy learning English question in this study, thirteen students responded to "A great deal test" and they believed that they had a lot of to enjoy learning English and only three the learners selected "Somewhat Not a very test" and the four students answered to "A lot test ". The analysis of this question is given below:

TABLE (3)

HOW DO YOU ENJOY LEARNING ENGLISH?

\begin{tabular}{|c|c|c|}
\hline \multirow{2}{*}{ enjoy learning English } & \multicolumn{2}{|c|}{ Students } \\
\cline { 2 - 3 } & Number & Percent \\
\hline A great deal & 13 & 65.0 \\
\hline A lot & 4 & 20.0 \\
\hline $\begin{array}{c}\text { Some what } \\
\text { not a very }\end{array}$ & 3 & 15.0 \\
\hline Total & 20 & 100.0 \\
\hline
\end{tabular}

\section{RESUlTS AND DisCUSSION}

In the following table, language attitude question has been developed for the analysis of data of the learning strategies in English language among the Iranian post-graduate students at Persian Gulf University in Iran. 13 of the students responded to "A great deal" to language attitude and 6 of them answered to" Somewhat not a very" to language attitude. The result of the analysis of language attitude is classified in the following table: 
TABLE (4)

LANGUAGE ATTITUDE:

\begin{tabular}{|c|c|c|}
\hline \multirow{2}{*}{ Language attitude } & Number & Percent \\
\cline { 2 - 3 } & 13 & 65.0 \\
\hline A great deal & 1 & 5.0 \\
\hline A lot & 6 & 30.0 \\
\hline $\begin{array}{c}\text { Some what } \\
\text { not a very }\end{array}$ & 20 & 100.0 \\
\hline Total & & \\
\hline
\end{tabular}

The questionnaire of this research paper was designed to investigate about the learning strategies in EFL setting in Iran. This test was designed based on the following results of the various analyses regarding to the students in the research article. The twenty nine statements of this test are given in the three parts as follows:

TABLE (5)

LEARNING STRATEGIES QUESTIONNAIRE (PART 1)

\begin{tabular}{|c|c|c|c|c|}
\hline \multirow[t]{3}{*}{ Statements } & No & A little & Good & Best \\
\hline & Frequency & Frequency & Frequency & Frequency \\
\hline & Percent & Percent & Percent & Percent \\
\hline 1. In English class, I like to learn by reading. & $\begin{array}{l}1 \\
5 \%\end{array}$ & $\begin{array}{l}3 \\
15 \%\end{array}$ & $\begin{array}{l}12 \\
60 \%\end{array}$ & $\begin{array}{l}4 \\
20 \%\end{array}$ \\
\hline 2. In class, I like to listen and use cassettes. & $\begin{array}{l}1 \\
5 \%\end{array}$ & $\begin{array}{l}5 \\
25 \%\end{array}$ & $\begin{array}{l}10 \\
50 \%\end{array}$ & $\begin{array}{l}4 \\
20 \%\end{array}$ \\
\hline 3. In class, I like to learn by games. & $\begin{array}{l}2 \\
10 \%\end{array}$ & $\begin{array}{l}7 \\
35 \%\end{array}$ & $\begin{array}{l}5 \\
25 \%\end{array}$ & $\begin{array}{l}6 \\
30 \%\end{array}$ \\
\hline 4. In class, I like to learn by conversation. & $\begin{array}{l}0 \\
0 \%\end{array}$ & $\begin{array}{l}3 \\
15 \%\end{array}$ & $\begin{array}{l}6 \\
30 \%\end{array}$ & $\begin{array}{l}11 \\
55 \%\end{array}$ \\
\hline 5. In class, I like to learn by pictures, films, and video. & $\begin{array}{l}0 \\
0 \% \\
\end{array}$ & $\begin{array}{l}2 \\
10 \%\end{array}$ & $\begin{array}{l}2 \\
10 \%\end{array}$ & $\begin{array}{l}16 \\
80 \%\end{array}$ \\
\hline 6. I want to write everything in a note book. & $\begin{array}{l}2 \\
10 \%\end{array}$ & $\begin{array}{l}8 \\
40 \%\end{array}$ & $\begin{array}{l}5 \\
25 \%\end{array}$ & $\begin{array}{l}5 \\
25 \%\end{array}$ \\
\hline 7. I like to have my own textbook. & $\begin{array}{l}2 \\
10 \%\end{array}$ & $\begin{array}{l}3 \\
15 \%\end{array}$ & $\begin{array}{l}6 \\
30 \%\end{array}$ & $\begin{array}{l}9 \\
45 \%\end{array}$ \\
\hline 8. I like the teacher to explain everything to us. & $\begin{array}{l}1 \\
5 \%\end{array}$ & $\begin{array}{l}2 \\
10 \%\end{array}$ & $\begin{array}{l}8 \\
40 \%\end{array}$ & $\begin{array}{l}9 \\
45 \%\end{array}$ \\
\hline 9. I like the teacher to give us problems to work on. & $\begin{array}{l}0 \\
0 \%\end{array}$ & $\begin{array}{l}3 \\
15 \%\end{array}$ & $\begin{array}{l}9 \\
45 \%\end{array}$ & $\begin{array}{l}8 \\
40 \%\end{array}$ \\
\hline 10.I like the teacher to help me talk about by interests. & $\begin{array}{l}0 \\
0 \%\end{array}$ & $\begin{array}{l}3 \\
15 \%\end{array}$ & $\begin{array}{l}10 \\
50 \%\end{array}$ & $\begin{array}{l}7 \\
35 \%\end{array}$ \\
\hline
\end{tabular}

On the basis of Table number 5, the number of responses found by the students to the first statement, has been identified as 12 which came to $60 \%$ for "good" item and the answer of 1 of the students was "no" which came to $5 \%$. . What it is interesting for us is that English reading in Iranian education has vital role and all of the Iranian schools, colleges and universities involved in reading skill in English as the major important syllabus in teaching and reading in Iran. Khansir and Gholami Dashti (2014) supported the claim that English reading is used as one of the main subject in Iranian education from School to University. The second question of this table, In class, I like to listen and use cassettes, the total number of the responses found for "good" item was 10 which came to $50 \%$ and the response of one student was "no" which came to 5\%. Today the role of educational technology is very important for teaching English in EFL class, and this technology has been using in Iranian education in teaching English in Iran. The next statement of this test included In class, I like to learn by games, the most participants answered to " a little" item which was 7 which came to $35 \%$ and 6 of the participants answered to "best" item which came to 30\% in this table. This question illustrated the games as one of an English language strategies can be used in increasing the knowledge of English among Iranian Students. In class, I like to learn by conversation was one of the statements found in this table. 11 of the students responded to "best "item which came to55\% and 6 of them answered to good item which came to $30 \%$. From this test of this questionnaire, we can say that conversation as one of English strategies is very important for the development of the speaking and listening skills in EFL class. In class, I like to learn by pictures, films, and video was one of the statements of this table. 16 of the Iranian students responded to "best" item which came to $80 \%$ and 2 of the students responded to "good" item which came to $10 \%$. The response of this statement illustrated that English teacher should give more focuses on pictures, films and video materials for teaching English in their class. This study strongly advise English teachers to spend a couple of hours a time process (a month or more) searching the English technology for new information on teaching young and advanced students. What is important for teaching language is that teachers should use a meaningful tool to facilitate the learning of a language in their class.

The next statement of this table 5, I want to write everything in a note book, 8 of the students angered to "a little" item which came to $40 \%$ and 2 of the students answered to "no" item which came to $10 \%$. It may be seen that in the statement of the number 6, nearly half of the students did not want to write everything in their note book. In statement No 7, I like to have my own textbook, 9 of the students answered to "best" item which came to $45 \%$ and 6 of the learners 
answered to "good "item which came to $30 \%$. Here the students seem to like to have their own text book. In the history of English language teaching, information about a variety of English strategies and techniques have been presented including specific suggestions for using different textbooks to teach English. Sivakumar (1994) supported our discussion and argued that text book is a coherent body of teaching and learning materials, and it has focal point for teacher and learner and governs the daily activities inside and outside the classroom. In statement No $8, I$ like the teacher to explain everything to us, nine students of this university answered to" best" item which came to $45 \%$ and 8 of them answered to "good" item which came to $40 \%$. From the statement No 8 , we can say that a teacher should give enough importance reply to the students' answers in class and the teacher should increase his/ her English knowledge. Regarding to this statement, Mansouri Nejad et al (2019) argued that teachers should use internet and research articles and technology as part of modern life which facilities quick and essay access to information. Teachers should more eager to get more information relating to teaching English in their class. In statement No 9, I like the teacher to give us problems to work on, the response of 9 of the learners was "good" item which came to $45 \%$ and 8 of the students was" best" item which came to $40 \%$. On the basis of this statement, Khansir (2014) argued that English teachers are always importance as one of the educational triangle in teaching English to English learners in target language. Thus, the teachers use techniques, approaches and methods in teaching English in ELT classrooms. Thus, the last statement of this table, I like the teacher to help me talk about by interests, ten students of this study answered to "good" item which came to $50 \%$ and seven students answered to "best" item which came to 35\%. According to this statement, English teachers of the students must more spend time working with them in class. Ur (1996) argued that most of my trainees requested their teachers as in some way pushing the trainees to intent to give of their best, though there was by no means a consensus on the most common or successful methods.

TABLE (5)

LEARNING STRATEGIES QUESTIONNAIRE (PART 2)

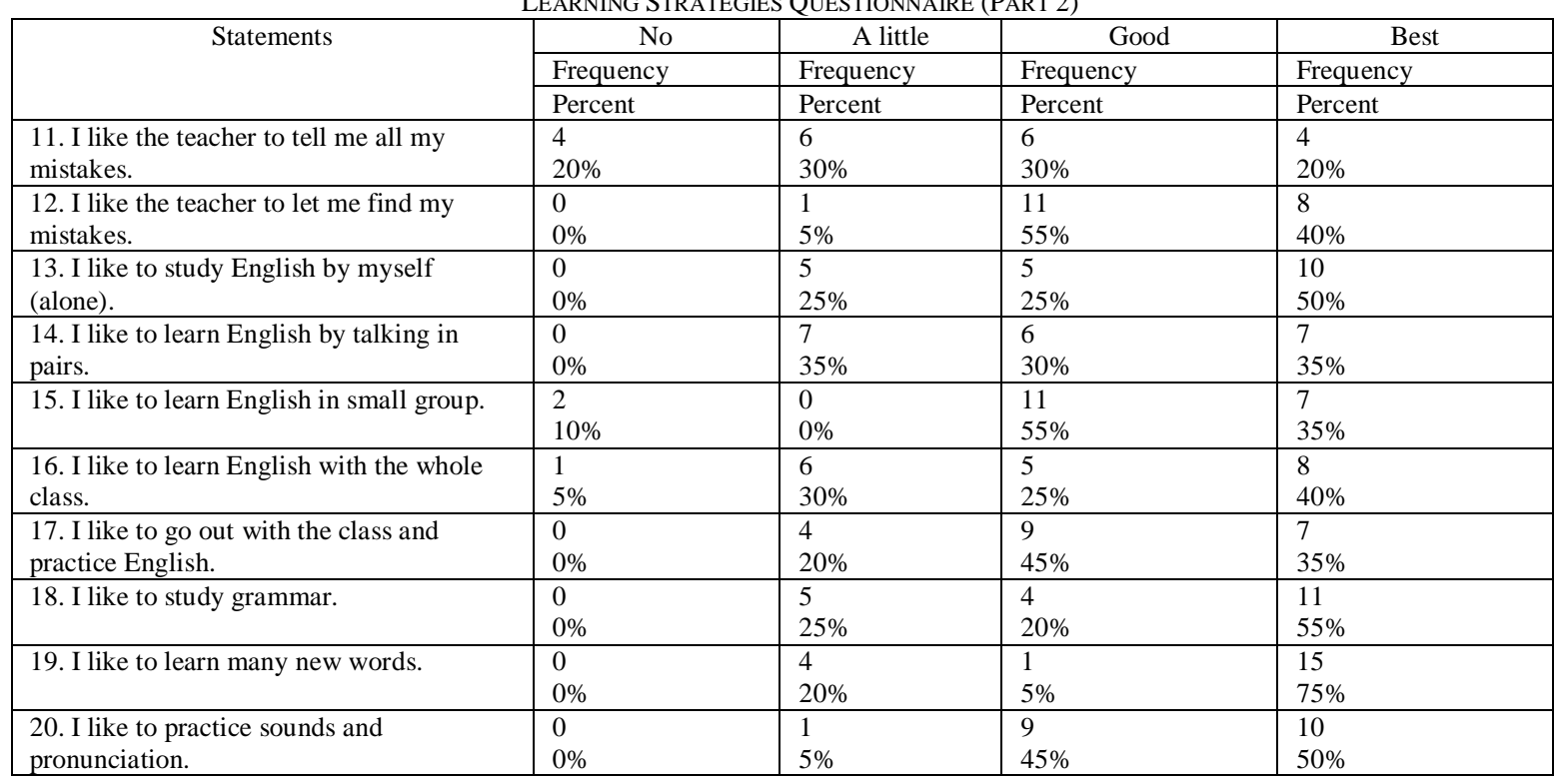

In terms of this table, it has been observed by the investigators of this study will be discussed from the question of 11 to 20. The first statement of this part, I like the teacher to tell me all my mistakes, the response of 6 of the learners was "good" item which came to $30 \%$ and 4 of the learners' answers was" best" item which came to $20 \%$. Mistakes and errors have a special place in teaching English in EFL setting. Mistakes and errors are those which appear in words, grammar and punctuation which are given in the written and spoken by English learners. Khansir and Pakdel (2020) argued that learning and teaching strategies and interference of mother tongue have been the other reasons for learners' errors. They added that we can help the EFL students through error analysis so that English foreign students can make progress in learning English. Khansir and Pakdel (2018a) added that "most of errors among the students can be replaced by remedial measures through the instructional materials and teachings-learning strategies"(p.536). The second statement, $I$ like the teacher to let me find my mistakes, 11 of the students' answers was "good" item which came to $55 \%$ and 8 of them answered to "best "item which came to $40 \%$. Khansir and Pakdel (2018b) said that some of the student's errors may be due to mistakes and carelessness and they preferred that all of the student's errors are not necessary for requiring the same remedial treatment. Ur (1996) mentioned that "in the context of teaching in general, feedback is information that is given to the learner about his or her performance of a learning task, usually with the objective of improving this performance" (p. 242). . In statement No 13, I like to study English by myself (alone), the answer of the ten students of this research work was "best" item which came to $50 \%$ and the answer of five of the students was "good" item which came to $25 \%$. This statement indicated that $75 \%$ of the students liked to study English by themselves (alone) and without class. In the statement No 14, I like to learn English by talking in pair, 7 of the students responded to "a little" 
item which came to $35 \%$ and 7 of them also answered to" best "item which came to $35 \%$. This statement showed that all of the learners did not like to learn English in pairs. The next statement of this part (No 15), I like to learn English in small group, 11 of the students responded to "good" item which came to 55\% and 7 of them responded to "best" item which came to $35 \%$ and only two students responded to "no "item which came to $10 \%$. On the basis of this statement, the learners of this study liked to learn English in small group. On the basis of the statement No 16, I like to learn English with the whole class, 8 of the students responded to best item which came to $40 \%$ and 6 of the students responded to a little item which came to $30 \%$. This statement also showed that nearly half of the students like to learn English with the whole class. In the statement No 17, I like to go out with the class and practice English, 9 of the learners answered to good item which came to $45 \%$ and 7 of the students responded to best item which came to $35 \%$. As it is mentioned in this question, more than $75 \%$ of the students was agree with go out with class and practice English. In the statement No 18, I like to study grammar, 11 of the learners of this study answered to" best" item which came to $55 \%$ and 4 of the learners responded to "good" item which came to 20\%. In the history of English in EFL classrooms, Grammar has played a vital role in teaching English in Iran. Freeman (2003) mentioned that "grammar is an area of knowledge that linguists and language teachers study (p, 13)". According to Khansir and Pakdel (2016), many scholars believed that the knowledge of English grammar is needed to teach English in English language teaching class. In the statement No 19, I like to learn many new words, 15 of the students responded to" best" item which came to $75 \%$ and 4 of the students answered to "a little" item which came to $20 \%$. Each language has words, and teaching English words is known as one of the important aspect of language development in EFL class. Gas and Selinker (2001) supported the role of words in the development of language teaching and argued that the knowledge of lexical skills is necessary for language learner for producing sentences and to understand them correctly. Khansir and Mosaddegh (2014) mentioned that vocabulary learning is very important and it can be used as the central and essential aspect of language in the process of second/foreign language learning. Nation (2003) believed that teachers can help learners figure out meaning on their own through facilitating vocabulary learning by teaching strategies and teaching learners useful words. In the last statement of this part, I like to practice sounds and pronunciation, 10 of the learners responded to best item which came to50\% and 9 of them answered to good item which came to 45\%. However, it is clear that the role of pronunciation is very important in developing speaking skill in English as a foreign or second language. Khansir and Tajeri (2015) mentioned that one of the most important factors in teaching and learning a target language is learning correct pronunciation of English words.

TABLE (5)

LEARNING STRATEGIES QUESTIONNAIRE (PART 3)

\begin{tabular}{|l|l|l|l|l|}
\hline \multirow{2}{*}{ Statements } & \multicolumn{2}{|c|}{ No } & \multicolumn{1}{c|}{ A little } & \multicolumn{1}{c|}{ Bood } \\
\cline { 2 - 5 } & Frequency & Frequency & Frequency & Frequency \\
\cline { 2 - 5 } & Percent & Percent & Percent & Percent \\
\hline 21. I like to learn English words by & 2 & 4 & 9 & 5 \\
seeing them. & $10 \%$ & $20 \%$ & $45 \%$ & $25 \%$ \\
\hline 22. I like to learn English words by & 0 & 6 & 4 & 10 \\
hearing them. & $0 \%$ & $30 \%$ & $20 \%$ & $50 \%$ \\
\hline 23. I like to learn English words by & 0 & 10 & 5 & 5 \\
doing something. & $0 \%$ & $50 \%$ & $25 \%$ & $25 \%$ \\
\hline 24. at home, , like to learn by & 0 & 2 & 4 & 14 \\
reading newspapers, etc. & $0 \%$ & $10 \%$ & $20 \%$ & $70 \%$ \\
\hline 25. at home, I like to learn by & 7 & 4 & 4 & 5 \\
watching TV in English. & $35 \%$ & $20 \%$ & $20 \%$ & $25 \%$ \\
\hline 26. at home, , like to learn by using & 0 & 4 & 6 & 10 \\
cassettes. & $0 \%$ & $20 \%$ & $40 \%$ & $50 \%$ \\
\hline 27. at home, I like to learn by & 0 & 3 & $20 \%$ & 13 \\
studying English books. & $0 \%$ & $15 \%$ & 4 & $65 \%$ \\
\hline 28. I like to learn by talking to & 0 & 1 & $20 \%$ & 15 \\
friends in English. & $0 \%$ & $5 \%$ & 4 & $75 \%$ \\
\hline 29. I like to learn by watching, & 0 & 4 & $20 \%$ & 12 \\
listening to native speakers. & $0 \%$ & $20 \%$ & & $60 \%$ \\
\hline
\end{tabular}

From this table, (5 ,part 3), the first statement No, 21, I like to learn English words by seeing them, 9 of the learners answered to "good" item which came to $45 \%$ and 5 of them answered to "best" item which came to $24 \%$. One of the important materials used in teaching English is reading in Iran. In the discussion of this statement, we followed the idea of Linse (2005); reading is a set of skills that involves making sense and deriving meaning from the printed words. What is important is that first of all students face with words and read them. In the statement No 22, I like to learn English words by hearing them, 10 of the students responded to best item which came to $50 \%$ and 6 of the students answered to a little item which came to $30 \%$. Listening skill is receptive skill because; the focus is on receiving information from an outside source. Teacher should help the students engage in listening words, tasks and activities. According the next statement, I like to learn English words by doing something, 10 of the students answered to" a little "item which came to $50 \%$ and 5 of the learners answered to "good" item which came to $25 \%$ and 5 of them answered to" best "item which came to $25 \%$. The result of this question showed that the Iranian students did not like to use English learning strategy. The statement no 24, at home, I like to learn by reading newspapers, etc. 14 of the learners 
answered to best item which came to $70 \%$ and 4 of them answered to good item which came to $20 \%$. Reading newspaper is one of the learning strategies develops the knowledge of English students in EFL class especially in Iran. In the statement No 25, at home, I like to learn by watching TV in English, 7 of the students responded to "no" item which came to $35 \%$ and 5 of the students responded to" best" item which came to $25 \%$ and 4 of the students responded to "good "item which came to $20 \%$. In EFL setting, TV has not good place in developing the knowledge of English learners because; in EFL setting, there are not enough English TV programs. Thus, there are a few TV programs in Iran. In the statement No 26, at home, I like to learn by using cassettes, 10 of the learners answered to best item which came to $50 \%$ and 6 of them answered to good item which came to $30 \%$. In Iran, universities have language labs for teaching English and then in these labs have educational facilities such as tape or cassette recorders. In the statement No 27, at home, I like to learn by studying English books, 13 of the learners answered to "best" item which came to $65 \%$ and 4 of them answered to "good" item which came to 20\%. A question arises why the students liked to learn English by studying English books, because, there are English books in Iran and the students can access the English books more easily than other English materials. In the statement No 28, I like to learn by talking to friends in English, 15 of the learners answered to "best" item which came to $75 \%$ and 4 of the learners answered to" good" item which came to $20 \%$. Thus, one of the best ways is to prepare classroom activities for students to work together in an ELT class. However, the development of English language skills is needed to pay attention in most of the English classes and the teacher gives more opportunities to work together in English class. The last statement of this table, I like to learn by watching, listening to native speakers, 12 of the students answered to "best" item which came to $60 \%$ and 4 of the learners answered to "good "item which came to $20 \%$ and finally 4 of them answered to "a little" item which came to $20 \%$. This statement indicated that the students liked to meet English native speakers to improve their English. Use of English native speakers help the learners reduces the communication errors in English.

\section{CONCLUSION}

Any learning strategy should be planned well in advance to be successful and English classroom teaching is no exception. A good and careful planning of learning strategy ensures success and creates confidence in the minds of English teacher and students in ELT class. Thus an experienced teacher help the students improve their English by using learning strategy in English classroom. A learning strategy should states the objectives of the lesson in clear terms, mention which types of teaching aids to be used for the lesson. Teaching English and leaning strategies are related to each other so much that they are like the two sides of a coin. A teacher should be cautious in using learning strategies in teaching English in class. The ability to use English needs learning strategies that help EFL students use English language in class. Therefore, the results of this article showed that there is a significant difference in learning strategies to get the English knowledge of EFL students in their class. In others word, the hypothesis of this study was accepted. The conclusion of this study tells us that learning strategy method is a useful method for English for English foreign language courses where students learn English for their educational purposes.

\section{REFERENCES}

[1] Anderson, N.J. (2005). L2 learning strategies. In Hinkel, E. (Ed.), Handbook of Research in Second Language Teaching and Learning. Erlbaum, Mahwah, NJ, pp. 757-771.

[2] Birjandi, P., Mosallanejad, P. \& Bagheridoust, E. (2006). Principles of Teaching Foreign Languages. Tehran: Rahrovan Publications.

[3] Birjandi, P. \& Mosallanejad, P. (2010). FL/SL Teaching and Learning. Tehran: Sepahan Publication.

[4] Cohen, A.D. (1998). Strategies in Learning and Using a Second Language. Longman, London.

[5] Ellis, R. (2003). Second Language Acquisition. Oxford: Oxford University Press.

[6] Freeman, D.L., (2003). Teaching Language from Grammar to Grammar. Canada: Heinle.

[7] Gas, S. \& Selinker, L. (2001). Second language acquisition. Manhwah: Lawrebce Erlbaum Associates.

[8] Johnson, K., \& Johnson, H. (1999). Encyclopedic Dictionary of Applied Linguistics. UK: Blackwell Publishers Ltd.

[9] Khansir, A.A. (2014). Teaching English is Art and English Teacher is Artist. International J. Soc. Sci. \& Education, 4(4), 838843.

[10] Khansir, A.A. \& Mosaddegh, A. (2014). The Impact of Translation and Pictorial Methods on Iranian EFL Learner's Vocabulary Learning and Retention. International Journal of English Language and Literature Studies, 3(3), 250-265.

[11] Khansir, A.A., \& Gholami Dashti, J. (2014). The Effect of Question-Generation Strategy on Iranian EFL Learners' Reading Comprehension Development. English Language Teaching, 7(4), 38-45.

[12] Khansir, A.A. \& Tajeri, M. (2015). The Relationship between Spelling and Pronunciation in English Language. Language in India, 15(12), 57-69.

[13] Khansir, A.A. \& Pakdel, F. (2016). Place of Grammar in English Language Teaching. Language in India, 16(2), 1-10.

[14] Khansir, A. A., \& Pakdel, F. (2018a). Study of Errors and English Language Teaching: A Systematic Review. The Journal of Social Sciences Research, 4(12), 531-538.

[15] Khansir, A. A., \& Pakdel, F. (2018b). Place of Error Correction in English Language teaching. Educational Process: International Journal, 7(3), 189-199.

[16] Khansir, A.A. (2020). The Effect of Using Discussion Method in Promoting English Language Knowledge among English Foreign Language Learners. SOCIALSCI Journal 8 (3), 71-80. 
[17] Khansir, A.A. \& Pakdel, F. (2020). A Study of Written Errors of Iranian Learners: A Systematic Review. Theory and Practice in Language Studies, 10(8) 982-987.

[18] Leaver, B, L, Ehrman, M, and Shekhtman, B. (2005). Achieving Success in Second Language Acquisition. UK: Cambridge University Press.

[19] Linse, C.T. (2005). Practical English Language Teaching: Young Learners. North America: McGraw Hill.

[20] Mandasari, B \& Oktaviani, L. (2018). English Language Learning Strategies: An Exploratory Study of Management and Engineering Students. Premise: Journal of English Education and Applied Linguistics, 7(2), 61-78.

[21] Mansouri Nejad, A, Pakdel, F. \& Khansir, A. A. (2019). Interaction between Language Testing Research and Classroom Testing Practice Educational Process: International Journal, 8(1), 59-71.

[22] Matthews, P.H. (2011). Concise Dictionary of Linguistics. Oxford: Oxford University Press.

[23] Naiman, N., Frohlich, M., Stern, H. \& Tedesco, A. (1978). The Good Language Learner Research in Education Series no.7. Toronto: OIES.

[24] Nation, L.S.P. (2003). Vocabulary. In D. Nunan (ed.), Practical English Language Teaching. (D. Nunan ed.), New York, NY: McGraw-Hill, 129-152.

[25] Nunan, D. (2001). Second Language Teaching \& Learning. USA: HEINLE\& HEI NLE Publisher.

[26] O'Malley, J.M. \& Chamot, A.U. (1990). Learning strategies in second language acquisition. Cambridge: U Cambridge University Press.

[27] Oxford, R. (1990). Language Learning Strategies: What Every Teacher Should Know. USA: HEINLE CENGAGE Learning.

[28] Oxford, R.L., Anderson, N. (1995). A cross cultural view of learning styles. Language Teaching, 28 (4), 201-215.

[29] Ravindra Sastry, R. (1984). Scientific Method: Research Method in Social Sciences. New Delhi: Sterling Publishers.

[30] Reid, J.M. (1987). The learning style preferences of ESL students. TESOL Quarterly 21 (1), 87-111.

[31] Scarcella, R., \& Oxford, R. (1992). The Tapestry of Language Learning: Individual in the Communicative Classroom. Boston, MA: Heinle \& Heinle.

[32] Sivakumar, C. (1994). A Linguistic Study of the Problems in Learning Tamil by Tribal Children of the Nilgiris. India: CILL.

[33] Souriyavongsa, T., Jafre Zainol Abidin, M., Sam, R., Lai Mei, L., \& Britto Aloysius, I. (2013). Investigating Learning English Strategies and English Needs of Undergraduate Students at the National University of Laos. English Language Teaching, 6, (10), 57_71.

[34] Ur, P. (1996). A Course in Language Teaching. Cambridge: Cambridge University Press.

[35] Willing, K. (1994). Learning Strategies in Adult Migrant Education. Australia: National Centre for English Language Teaching and Research, Sydney.

[36] Wong, L, .C Nunan, D. (2011). The learning styles and strategies of effective language learners. System, 39 (2).144-163.

Ali Akbar Khansir is Associate Professor of English Language Teaching at the Bushehr University of Medical Sciences, Bushehr, Iran. He has completed M.A. in English Language Teaching at the Aligarh Muslim University in 2003 and PhD in English Language Teaching at the Mysore University in 2010 in India He is the author of many books in the field of Applied Linguistics and English Language Teaching and published more than sixty articles in various Journals of English Language Teaching and Linguistics.

Fatemeh Ghani Dehkordi is a PhD student in Faculty of Paramedical Sciences, Shiraz University of Medical Sciences, Shiraz, Iran.

Mostafa Mirzaei is an English Language teacher at Department of English Bushehr University of Medical Sciences, Bushehr, Iran. 